\title{
PENGOLAHAN SAMPAH MELALUI KOMPOSTER DAN BIOPORI DI DESA SEDAPURKLAGEN BENJENG GRESIK
}

\author{
Anak Agung Sagung Alit Widyastuty ${ }^{1)}$, Abdul Haqqi Adnan ${ }^{2)}$, Nurul Arijah Atrabina ${ }^{3)}$ \\ ${ }^{1}$ Fakultas Teknik Sipil dan Perencanaan Universitas PGRI Adi Buana Surabaya \\ Email: sagungalit@unipasby.ac.id \\ ${ }^{2}$ Fakultas Keguruan dan Ilmu Pendidikan, Pendidikan Kepelatihan Olahraga Universitas PGRI Adi Buana \\ Surabaya \\ Email: abdulhaqqiadnan@gmail.com \\ ${ }^{3}$ Fakultas Keguruan dan Ilmu Pendidikan, Pendidikan Guru Sekolah Dasar Universitas PGRI Adi Buana \\ Surabaya \\ Email: atra_riza@yahoo.com
}

\begin{abstract}
Abstrak
Sampah merupakan permasalahan yang harus dihadapi masyarakat permukiman baik yang di permukiman perkotaan maupun pedesaan, sehingga perlu penanganan yang secara tersistematis, terstruktur dan berkelanjutan. Penanganan sampah secara Konvensional yang telah diterapkan oleh masyarakat tidak bisa menghasilkan suatu solusi yang tepat, hal ini terbukti masih banyaknya volume sampah yang belum terkelola dengan baik. Tujuan dari pelaksanaan kegiatan pengabdian pada masyarakat di desa Sedapurklagen Benjeng Gresik adalah melakukan pemanfaatan sampah rumah tangga melalui kompoter dan biopori dan juga penerapan Biopori untuk pengolahan sampah rumah tangga yang juga dapat mengurangi genangan air pada saat hujan. Metode pelaksaan yang digunakan agar tujuan dari kegiatan Pengabdian ini adalah pemberdayaan masyarakat tentang pengelolaan sampah rumah tangga untuk dijadikan kompos melalui komposter, dan juga pelatihan pembuatan kompos dari komposter dan biopori. Sasaran dari kegiatan ini adalah ibu - ibu pengerak PKK di Desa Sedapurklagen Benjeng Gresik. Hasil dari kegiatan pengabdian ini adalah masyarakat sudah mulai mengolah sampah organic untuk pembuatan kompos dan juta pembuatan pipa biopori di sekitar Posyandu Sedapurklagen Gresik untuk mengurangi adanya genangan air pada saat musim hujan.
\end{abstract}

Kata Kunci: Kompos, Biopori, sampah rumah tangga, Komposter.

\begin{abstract}
Waste is a problem that must be faced by residential communities both in urban and rural settlements, so it needs to be systematically structured and sustainable. Conventional waste handling that has been implemented by the community cannot produce an appropriate solution, this is evident that there is still a large volume of waste that has not been managed properly. The purpose of implementing community service activities in the village of Sedapurklagen in Benjeng Gresik is to utilize household waste through compoter and biopori as well as the application of Biopori to treat household waste that can also reduce waterlogging during rain. The implementation method is used so that the purpose of this service activity is to empower the community about managing household waste to be composted through composter, as well as training on composting from composter and biopori. The target of this activity is the mothers of family welfare coaching (PKK) in the village of Sedapurklagen, Benjeng Gresik. The result of this service is that the community has begun to process organic waste to make compost and million biopori pipes around the Posapur, Sedapurklagen Gresik to reduce the presence of standing water during the rainy season.
\end{abstract}

Keywords : Compost, Biopori, household waste, Komposter. 


\section{PENDAHULUAN}

Sampah merupakan limbah yang bersifat padat yang terdiri dari bahan organic maupun anorganik yang sudah dianggap tidak berguna lagi dan harus dikelola dengan baik agar tidak mengganggu atau membahayakan lingkungan dan melindungi investasi pembangunan (Anonymous, 2002). Pertumbuhan penduduk merupakan salah satu menyebab meningkatnya limbah padat dapat disebabkan oleh pertumbuhan. Meningkatnya jumlah limbah padat yang dihasilkan rumah tangga berkorelasi positif dengan jumlah penduduk disetiap daerah sehingga menyebabkan jumlah sampah yang dihasilkan rumah tangga juga semakin meningkat. Diperkirakan setiap rumah tangga di Indonesia dapat menghasilkan sampah sebanyak 0,52 kg/jiwa/hari (Jenna R. Jambeck 2015 dalam BPS, 2017). Produksi sampah yang meningkat tiap tahunnya bila tidak disertai dengan pengelolaan yang baik dan berkelanjutan akan menimbulkan pencemaran, baik pencemaran tanah, air maupun udara. Konsep pengelolaan sampah organic yang dihasilkan dari limbah rumah tangga melalui konsep composting merupakan konsep pengelolaan sampah rumah tangga menjadi kompos yang mempertimbangkan system desentralisasi dan sentralisasi composting dengan pendekatan wilayah (Wahyono, 2016).

Hal pertama yang perlu diketahui dalam pengelolaan sampah adalah mengetahui karakter dari sampah yang ditimbulkan oleh masyarakt (Bahar, 2008). Karakter sampah yang dapat dikenali sebagai berikut : tingkat produksi sampah, komposisi sampah dan kandungannya, kecenderungan perubahan dari waktu ke waktu (Bahar, 2008). Pemilahan sampah sendiri sampai saat ini masih merupakan masalah bagi banyak orang dan rumah tangga. Padahal apabila sampah dipilah sesuai dengan jenis sampah organic dan anorganik dan dikelola dengan baik lebih lanjut dapat memberikan nilai lebih (Hariyono, Suciarto, Kusdiartini, \& Listiati, 2013).
Selain permasalahan sampah, hampir seluruh daerah di propinsi Jawa Timur memiliki Potensi rawan bencana, tak terkecuali Kabupaten Gresik yang memiliki luas wilayah mencapai $1.191,25$ Kilometer persegi dengan panjang pantai \pm 140 Kilometer terbagi dalam 18 kecamatan dan terdiri dari 330 desa dan 26 kelurahan (Dikominfo, 2017). Kejadian bencana Banjir hamper setiap tahun di rasakan oleh warga masyarakat Desa Sedapurklagen Kecamatan Benjeng Gresik. Berdasarkan data Badan Penanggulangan Bencana Daerah (BPBD) Gresik ada 9 desa yang terendam banjir, desa yang dimaksud itu diantaranya Desa Sedapurklagen yant ergenang air setinggi 30 - $40 \mathrm{~cm}$ serta sawah 63 hektar (Setiono, 2017).

Dengan demikian maka perlu dilakukan suatu penanggulangan untuk menerapkan upaya pengurangan sampah dengan membuat pupuk kompos dan juga alat untuk menggemburkan tanah. Pengabdian ini dilakukan demi terciptanya generasi yang peduli lingkungan yang berupaya mengelola lingkungan sebaik mungkin dan juga mengatasi kebanjiran.

Guna menanggulangi masalah banjir pada pelaksanaan pengabdian ini menggunakan teknologi pipa resapan yang biasa disebut pipa biopori. Selain itu teknologi lain yang digunakan untuk mengolahan sampah adalah teknologi sederhana yaitu tong - tong pengolahan sampah organic menjadi kompos yang biasa disebut tong komposter.

Di tengah makin terbatasnya lahan untuk mengolah sampah secara tradisional, komposter skala rumah tangga ini dapat dibuat dengan tujuan untuk mengolah sampah organik dapur menjadi pupuk kompos. Dalam pembuatannya lebih mudah karena hanya memodifikasi bahan jadi yang harganya lebih murah di pasaran dan dapat digunakan berkali-kali karena terbuat dari plastik yang tahan lama dan juga pupuk yang dihasilkan oleh tong sampah komposter dapat dijual kepada petani maupun masyarakat umum. 
Lubang Resapan Biopori adalah produk teknologi sederhana yang murah dan tidak memerlukan lahan yang luas, juga cepat serta mudah dalam pembuatannya (Mulyaningsih, Purwanto, \& Sasongko, 2014). Selain itu Lubang Respan Biopori dapat membantu menurunkan kerentanan kota terhadap bencana banjir, kekeringan akibat kekurangan sumber air dan membantu mengurangi beban sampah organic. Sehingga Lubang Resapan Biopori tepat diterapkan pada lokasi yang memiliki kepadatan bangunan dan permukiman penduduk.

Pencetus pembuatan biopori muncul pada saat Ir. Kamir R. Brata, MSc., dosen Ilmu Tanah dan Sumber Daya Lahan Institut Pertanian Bogor meneliti bongkahan tanah kawasan hutan konservasi di Sumatra. Pada bongkahan itu terdapat ratusan lubang mirip terowongan yang berbentuk pori-pori. Lubang-lubang itu dibuat oleh semut, rayap, cacing, dan akar tanaman (Brata, K R 1990 di dalam Lindarto, Harisdani, \& Abdillah, 2018).

Lubang Biopori Satu bongkahan seukuran buah kelapa mengandung ratusan lubang yang menyerap air dikala hujan. Penelitian lebih lanjut menunjukkan adanya lubang tak kasatmata yang terdapat pada bongkahan, berupa ratusan lubang biopori. Lubanglubang ini berfungsi menyerap air, menyaring air bersih, mengurai sampah organik, serta menjaga unsur hara pada tanah.

Lubang-lubang biopori akan terisi udara, dan akan menjadi tempat berlalunya air dalam tanah. Bila lubang-lubang seperti ini dibuat dalam jumlah banyak maka kemampuan sebidang tanah untuk meresapkan air akan meningkat. Meningkatnya kemampuan tanah dalam meresapkan air akan memperkecil peluang terjadinya aliran air di permukaan tanah. Hal ini akan meminimalisir terjadinya kebanjiran.

\section{TINJAUAN PUSTAKA Tong Komposter \\ a) Komposter}

Kompos adalah bahan - bahan organic ( sampah - sampah organic ) yang telah megnalami proses pelapukan karena adaya interaksi antara mikroorganisme (bakteri pembusuk) yang bekerja di dalamnya (Deddy 2005 dalam Rangkuti, 2014). Bintoro (2008) dalam Rangkuti, (2014) menyatakan salah satu system pengomposan adalah system anaerob dimana pengolahan kompos mirip dengan system penambangan dan system aerob. Komposting memiliki peran penting dalam upaya pendauran ulang sampah karena kemampuannya mengubah sampah organic menjadi pupuk organic kompos (Sahwan, 2012). Composting merupakan proses dekomposisi bahan organic (sampah organic) secara biologis dalam kondisi aerobic dan termofilik terkendali menjadi produk stabil seperti humus, yaitu Kompos (Haug R.T 1980, Tchobanouglous G.H 1993, Epstein 1997 dalam Sahwan, 2012).

Kompos merupakan salah satu jenis pupuk organic (Sahwan, 2012). Pupuk organic adalah pupuk yang berasal dari tumbuhan mati, kotoran hewan dan atau bagian hewan dan atau limbah organic lainnya yang telah melalui proses rekayasa berbentuk padat atau cair dapat diperkaya dengan bahan mineral dan atau mikroba yang bermanfaat untuk emningkatkan kandungan hara dan bahan organic tanah, serta memperbaiki sifat fisik, kimia dan biologi tanah (Wahyono 2003 dalam Sahwan, 2012).

Pelaksanaan dalam kegiatan produksi kompo dari sampah yang dikumpulkan diharapkan dapat mengurangi kerugian sebelumnya. Pengolahan sampah menjadi pupuk merupakan cara untuk menghasilkan nilai ekonomi (Suartami, 2016). Dari penjelasan tentang kompos di atas maka kegiatan pengabdian ini menggunakan alat yang disebut tong sampah komposter. Tong sampah komposter adalah alat daur ulang dari tong bekas yang dimodifikasi menjadi alat pembuat kompos dari sampah organik rumah tangga yang dicampur dengan sampah yang sudah jadi menjadi kompos padat.

Tabung komposter ini terbuat dari platik untuk menghindari proses pengkaratan dan memiliki daya tahan pakai yang kuat. Tempat sampah ini memiliki dua sisi yang dipisahkan oleh sekat didalamnya yang berfungsi untuk memisahkan sampah padat dengan pupuk 
cair organic (Hartini, Mubarokah, \& Mahawati, 2018).

\section{b) Manfaat Tong Sampah Komposter}

1) Dalam pembuatannya lebih mudah dibuat karena hanya memodifikasi bahan jadi yang harganya lebih murah di pasarana dan dapat digunakan berkali-kali. Karena terbuat dari plastik yang tahan lama.

2) Pupuk yang dihasilkan oleh tong sampah komposter dapat dijual kepada petani maupun masyarakat umum.

\section{Biopori}

Fungsi hidrologi setiap bidang lahan secara alami adalah meresapkan air hujan yang jatuh di permukaan lahan (Widyastuti, 2013). Air hujan yang meresap ke dalam tanah akan menjadi cadangan air di daerah perakaran tanaman (ditahan dalam pori mikro) dan kelebihannya akan bergerak ke bawah melalui pori makro mengisi cadangan air bawah tanah (Widyastuti, 2013). Air yang sampai ke permukaan tanah dapat meresap ke dalam tanah melalui pori makro diantara agregat tanah dan terowongan - terowongan kecil yang dikenal dengan Biopori (biopore) (Widyastuti, 2013). System Biopori adalah usaha untuk meningkatkan kemampuan tanah dalam meresapkan air hujan melalui pengendalian aliran permukaan. Biopori juga digunakan sebagai simpanan dalam menampung dan meresapkan air tanah (Juliandari, Nirmala, \& Yuniarti, 2013).

Lubang Resapan Biopori menurut peraturan menteri Kehutanan nomor : P.70/Menhut-II/2008 tentang pedoman teknis rehabilitasi hutan dan lahan bagian $\mathrm{E}$ mempunyai pengertian adalah lubang lubang yang terbentuk di dalam tanah yang terbentuk akibat berbagai aktivitas organisme di dalamnya, seprti cacing, perakaran tanaman, rayap dan fauna tanah lainnya (Lindarto et al., 2018). Lubang - lubang yang terbentuk akan terisi udaara dan akan menjadi temat berlalunya air di dalam tanah (Lindarto et al., 2018).

Biopori merupakan ruang atau pori dalam tanah yang dibentuk oleh makhluk hidup, seperti mikroorganisme tanah dan akar tanaman. Bentuk biopori menyerupai liang (terowongan kecil) di dalam tanah dan bercabang-cabang dan sangat efektif untuk menyalurkan air dan udara ke dalam tanah (Brata \& Nelistya, 2008). Liang pori terbentuk oleh adanya pertumbuhan dan perkembangan akar tanaman, serta aktivitas fauna tanah seperti cacing tanah, rayap, dan semut di dalam tanah. Bentuk biopori meyerupai liang kecil dan bercabang-cabang yang sangat efektif menyerap air ke dalam tanah. Berbagai ukuran dan jenis organisme tanah hidup di antara pori-pori dan melalui pori tersebut organisme memperoleh air dan oksigen sedangkan untuk makanan diperoleh dari bahan organik berupa pelapukan sisasisa tanaman dan mahluk hidup lainnya (Brata \& Nelistya, 2008).

Populasi dan aktivitas organisme tanah dapat ditingkatkan dengan menyediakan bahan organik yang cukup di dalam tanah, sehingga organisme tanah akan memperoleh makanan yang cukup untuk hidup dan berkembang biak. Konversi kawasan bervegetasi alami menjadi kawasan pemukiman atau kegiatan lainnya akan mengakibatkan terjadinya pemadatan tanah sekaligus akan merusak liang pori di dalam tanah (Brata \& Nelistya, 2008). Hal tersebut tentu sangat berpengaruh terhadap menurunnya laju resapan air ke dalam tanah pada saat musim penghujan.

\section{Lubang Resapan Biopori}

Lubang Resapan Biopori (LRB) adalah lubang silindris yang dibuat secara vertikal ke dalam tanah dengan diameter $10-30 \mathrm{~cm}$ dan kedalaman sekitar $80 \mathrm{~cm}$ atau di dalam permukaan air tanah dangkal, tidak sampai melebihi kedalaman muka air tanah. Lubang diisi dengan sampah organik. Sampah berfungsi menghidupkan mikroorganisme tanah, seperti cacing tanah. Cacing ini nantinya bertugas membentuk pori-pori atau terowongan dalam tanah (biopori). Biopori secara harfiah merupakan lubang-lubang (pori-pori makro) di dalam tanah yang dibuat oleh jasad biologi tanah. Keberadaan biopori yang banyak, akan mempertinggi daya serap tanah terhadap air, karena air akan lebih 
mudah masuk ke dalam tubuh (profil) tanah (Brata \& Nelistya, 2008).

Penerapan teknologi lubang resapan biopori dimaksudkan untuk meningkatkan jumlah dan luas liang pori yang terbentuk kesegala arah di dalam tanah, dengan bertambahnya luas liang pori tersebut maka jumlah (volume) peresapan air kedalam tanah akan semakin meningkat. Sesuai dengan tujuannya adalah untuk meningkatkan peresapan air ke dalam tanah, maka pemasangan lubang resapan biopori harus ditempatkan pada lokasi yang dilalui air atau tampat-tempat di mana biasanya air tergenang pada saat hujan. Tempat yang dianjurkan untuk pemasangan biopori adalah di saluran pembuangan air hujan, sekeliling pohon, kontur taman, pada sisi pagar, dan tempat lain yang dianggap sesuai. Sudah semestinya biopori ditempatkan pada titik yang berpotensi terjadi genangan, karena pembuatan biopori pada lokasi yang agak tinggi maka laju resapan air tidak maksimal.

\section{Peranan Bahan Organik}

Menurut Brata \& Nelistya (2008) mengemukakan bahwa agar lubang biopori tetap berfungsi optimal maka secara rutin diisi dengan bahan organik, sehingga di dalam lubang resapan biopori akan tetap berlangsung proses pengomposan secara aerobik oleh mikroorganisme tanah. Bahan organik yang digunakan dapat diperoleh dari berbagai sumber antara lain sampah dapur rumah tangga, potongan/pangkasan tanaman, sisa produksi pertanian yang tidak dimanfaatkan dan sebagainya.

Pada pelaksanaan ini bahan organik yang digunakan adalah daun-daun kering dan basah, serta kulit buah, dengan pertimbangan bahwa daun-daun dan kulit buah mengandung nutrisi yang dibutuhkan oleh mikroorganisme tanah di samping itu bahan organik tersebut mudah diperoleh dalam jumlah yang banyak sehingga perlakuan lebih homogeny. Keberhasilan teknologi lubang resapan biopori sangat tergantung pada ketersediaan bahan makanan mikroorganisme yang berasal dari sampah organik .

\section{Manfaat Lubang Resapan Air}

Teknologi lubang resapan biopori memiliki manfaat yang sangat banyak namun secara garis besar adalah sebagai berikut:

a. Mengurangi genangan air

Pada daerah perkotaan umumnya pembangunan sangat berkembang maka semakin meningkat pula kawasan tertutup (kedap air) sehingga mengurangi daerah resapan yang mengakibatkan menurunnya volume resapan air ke dalam tanah. Di samping itu lahan terbuka di sekitar pemukiman/perumahan umumnya dalam keadaan padat akibat aktivitas manusia. Kondisi ini menyebabkan peningkatan jumlah air hujan terbuang sebagai air larian (run off water) yang mengakibatkan terjadi genangan, sehingga pada musim hujan akan terjadi banjir.

Menurut Rauf, n.d. (2009) untuk mengatasi banjir di daerah urban tidak hanya melalui perbaikan drainase, tetapi juga dengan memperbanyak daerah-daerah tangkapan air (water reservoir), salah satunya yaitu membuat lubang resapan biopori. Dengan menerapkan lubang resapan biopori maka liang biopori yang terbentuk akan berfungsi meningkatkan resapan air ke dalam tanah, sehingga penggunaan lubang resapan biopori dalam jumlah yang sesuai akan mengurangi terjadinya genangan dan pada akhirnya dapat mengendalikan banjir.

b. Menambah cadangan air tanah

Air hujan yang masuk ke dalam tanah dalam bentuk air bebas akan terus mengalami pergerakan perlahan-lahan menuju tempat yang terendah. Jika terus menerus diisi kembali, cadangan air bawah tanah akan dapat dipertahankan walaupun pemanfaatan air bawah tanah untuk kebutuhan manusia cukup tinggi (Asdak, 2014). Dengan meningkatnya resapan air ke dalam 
tanah tentu ketersediaan air di bawah tanah akan semakin meningkat pula jumlahnya. Ketersediaan cadangan air bawah tanah sangat penting dan wajib dipelihara, khususnya di daerah perkotaan karena air bawah tanah merupakan salah satu cadangan sumber air bersih bagi masyarakat dan pelaku usaha kegiatan.

c. Mengurangi volume sampah organik

Menurut Rauf, n.d. (2009) dengan menerapkan teknologi lubang resapan biopori maka sampah organik yang dihasilkan setiap hari tidak lagi menjadi masalah, tetapi dapat dimanfaatkan dengan memasukkannya ke dalam tanah yang digali (lubang resapan), untuk memperoleh makanannya mikroorganisme tanah akan menguraikan bahan organik tersebut, sehingga populasinya akan terus bertambah dan aktivitasnya akan membentuk pori-pori di dalam tanah.

d. Menyuburkan tanah

Ketika kita memasukkan sampah organik ke dalam lubang, akan terjadi proses biologis yang akan menjadikan sampah tersebut menjadi pupuk kompos. Dengan terbentuknya pupuk kompos di dalam lubang, tentu akan membuat tanah menjadi lebih subur.

e. Membantu mencegah terjadinya banjir

Dengan membuat lubang resapan biopori, dapat membantu air untuk segera masuk ke dalam tanah. Selain itu, sampah organik yang ada di dalam lubang merupakan makanan dari cacing tanah. Cacing yang masuk ke dalam lubang akan membuat terowongan-terowongan kecil di dalam tanah ketika menuju ke lubang yang berisi sampah organik. Hal ini tentu akan membuat air lebih cepat meresap ke dalam tanah.

\section{METODE PELAKSANAAN}

Pelaksanaan ini dilakukan pada tanggal 15 Februari 2017. di balai desa tepatnya di lahan penanaman dekat posyandu sedapurklagen benjeng gresik. Pemilihan tempat ini dilakukan karena lahan yang digunakan untuk menanam pipa biopori sangatlah strategis. Populasi yang digunakan yaitu karang taruna desa Sedapurklagen, sedangkan sampel yang digunakan yaitu karang taruna desa Sedapur klagen. Teknik pengumpulan data dalam penelitian ini yaitu observasi lapangan dan dokumentasi.

Berikut adalah alat dan bahan yang diperlukan untuk pembuatan tong sampah komposter dan pipa biopori, yakni:

\section{Alat dan Bahan}
a. Pipa Paralon
b. Tutup pipa
c. Gergaji besi
d. Tong
e. Pipa 1 inchi
f. Mata bor besi
g. LBU
h. TBU
i. Kran plastik
j. Meteran
k. Kasa plastik 2 meter
1. Kompos

\section{Langkah-langkah Pembuatan Tong Sampah Komposter}

a. Buat dua lubang udara di sisi kanan dan kiri tong sampah dengan menggunakan bor. Diameter lubang harus sama dengan diameter pipa paralon.

b. Buat catu lubang lagi di sisi lain tong, posisi lubang ketiga ini harus lebih rendah dari pada lubang sebelumnya atau sekitar $10 \mathrm{~cm}$ dari dasar tong.

c. Setelah itu buat lubang-lubang kecil di badan pipa paralon $13 \mathrm{~cm}$ dan pipa pralon $10 \mathrm{~cm}$ lalu bungkus badan pipa yang berlubang tersebut dengan kasa plastik hingga tertutup rapi.

d. Selanjutnya instalasi udara untuk komposter dapat dirangkai dimulai dari memasang kedua pipa paralon 
$13 \mathrm{~cm}$, masing-masing pada lubang kanan dan kiri. Kedua pipa dimasukkan dari arah dalam ke luar, pipa didorong dari dalam hingga keluar $3 \mathrm{~cm}$ dari lubang dan sisanya sekitar $10 \mathrm{~cm}$ berada di dalam tong.

e. Kedua ujung pipa yang mencuat keluar $3 \mathrm{~cm}$ tersebut kemudian ditutup dengan kasa plastik. Potong kasa plastik berbentuk lingkaran dengan diameter sekitar $1 \mathrm{~cm}$ lebih panjang dari diameter pipa. Beri lem PVC di sekitar ujung pipa lalu tempelkan kasa atur hingga tertutup rapi.

f. Selanjutnya kedua pipa $13 \mathrm{~cm}$ tadi disambung dengan sambungan pipa berbentuk T.

g. Dari kaki sambungan $\mathrm{T}$ tersebut dirangkaikan dengan pipa paralon 10 $\mathrm{cm}$.

h. Kemudian pasang sambungan pipa L pada bagian ujung bawah pipa paralon $10 \mathrm{~cm}$. Sambungan pipa L dipasang dengan arah kakinya mangarah ke lubang yang akan di pasangi kran (lubang ketiga).

i. Pasang kran plastik pada lubang ketiga tersebut.

j. Terakhir masukkan pipa paralon 9 $\mathrm{cm}$ untuk menyambung antara lubang kran plastik dengan pipa L.

\section{Langkah-Langkah Biopori}

Langkah Persiapan :

- Siapkan alat bor, tutup lubang dan pengeras bibir lubang (pipa paralon $10 \mathrm{~cm}$ atau adukan semen).

- Buat alur air menurut kontur teknis (agar air mengalir secara gravitasi).

Langkah Pelaksanaan :

a. Buat lubang silindriss secara vertikal ke dalam tanah dengan diameter 10$30 \mathrm{dm}$. kedalaman kurang lebih 80$100 \mathrm{~cm}$ atau tidak sampai melampaui muka air tanah bila air tanahnya dangkal. Jarak antar lubang antara $50-100 \mathrm{~cm}$.

b. Mulut lubang dapat diperkuat dengan semen selebar 2-3 cm dengan tebal 2 $\mathrm{cm}$ atau pipa paralon $10 \mathrm{~cm}$ di sekeliling mulut lubang.

c. Isi lubang dengan sampah organik yang berasal dari sampah dapur, sisa tanaman, dedaunan atau pangkasan rumpun atau kulit buah.

d. Sampah organik perlu selalu ditambahkan ke dalam lubang yang isinya sudah berkurang dan menyusut akibat proses pelapukan.

e. Kompos yang terbentuk dalam lubang dapat diambil pada setiap akhir musim kemarau bersamaan dengan pemeliharaan lubang resapan (Brata \& Nelistya, 2008).

\section{HASIL PELAKSANAAN}

Lokasi pelaksanaan berada di lahan penanaman dekat posyandu Sedapurklagen benjeng gresik. Jenis tanah di lokasi pelaksanaan ini adalah tanah berwarna cokelat dengan profil air tanah yang cukup tinggi di musim penghujan.

Pelaksanaan dengan menerapkan tong sampah komposter dengan cara mendaur ulang dari tong bekas yang dimodifikasi menjadi alat pembuat kompos dari sampah organik rumah tangga yang dicampur dengan sampah yang sudah jadi menjadi kompos padat. Setelah melakukan penerapan tong sampah komposter, selanjutnya melakukan penerapan untuk meminimalisir terjadinya banjir dengan membuat pipa biopori. Pipa biopori tersebut dilakukan persiapan diantaranya bor tanah, tutup lubang dan pengeras bibir lubang dengan menggunakan pipa paralon $10 \mathrm{~cm}$ dan dibuat alur air. Penelitian ini dilakukan dengan membuat \pm 10 lubang berbentuk silinder yang tersebar di lahan penanaman dekat posyandu sedapurklagen benjeng gresik dengan cara menggali didalam tanah menggunakan alat bor manual, berdiameter mata bor $20 \mathrm{~cm}$. Lubang digali dengan ukuran diameter $20 \mathrm{~cm}$ sedalam $80 \mathrm{~cm}$, kemudian mulut lubang dapat diperkuat dengan pipa paralon $10 \mathrm{~cm}$ di sekeliling mulut lubang. Gambar 1 merupakan pembuatan biopori untuk mencegah genangan air (run off water) di 
lahan penanaman dekat posyandu sedapurklagen benjeng gresik.

Setelah itu isi lubang dengan sampah organik yang berasal dari daun kering, daun basah, kulit buah dan sampah dapur. Sampah organik perlu selalu ditambahkan ke dalam lubang yang isinya sudah berkurang dan menyusut akibat proses pelapukan, hal ini dikarenakan sampah organik tersebut akan menjadi kompos yang dapat diambil pada setiap akhir musim kemarau bersamaan dengan pemeliharaan lubang resapan air. Sampah organik yang dimasukkan ke dalam lubang biopori tidak boleh melebihi paralon dan terlalu padat karena bakteri tidak akan bekerja maksimal dalam proses pembuatan pupuk kompos.

Biopori merupakan alat sederhana yang efektif dan efisien sehingga dalam pembuatannya, tidak membutuhkan biaya yang sangat besar. Tak hanya itu biopori memiliki dua fungsi yakni mengembalikan siklus hidrologi air dan sebagai media pembuatan pupuk kompos. Metode yang digunakan biopori dalam pembuatan pupuk kompos adalah metode yang natural atau alami karena bakteri dalam tanah berperan mengubah sampah organik menjadi pupuk kompos. Proses ini sangat alami sehingga kesuburan tanah tetap terjaga. Program pembangunan sanitasi pengembangan biopori dilakukan dengan memilih lokasi yang tepat untuk pembuatan biopori.

Biopori memiliki banyak fungsi, antara lain: memaksimalkan air yang meresap ke dalam tanah sehingga menambah air tanah dan mengembalikan siklus hidrologi air seperti semula. Biopori dapat digunakan sebagai pembuatan pupuk kompos alami dari sampah organik. Dengan demikian, biopori dapat mengurangi sampah organik sehingga sampah organik yang ada tidak terbuang sia sia dan dapat dimanfaatkan menjadi pupuk kompos. Seperti yang kita ketahui sampah dapat menghasilkan gas metan yang berbahaya dan menyebabkan terjadinya kerusakan lingkungan. Oleh karena itu biopori memiliki peranan penting dalam upaya menyelamatkan lingkungan. Biopori juga mengurangi genangan air atau run off water yang menimbulkan penyakit.

Pada umumnya run off water adalah salah satu tempat berkembang biaknya sarang nyamuk. Selain itu run off water dapat menimbulkan bau tak sedap sehingga menggangu pernapasan manusia. Biopori dapat mengurangi air hujan yang dibuang percuma ke laut. Mengurangi risiko banjir di musim hujan. Maksimalisasi peran dan aktivitas flora dan fauna tanah. Jika run off water dapat teratasi, maka aktivitas manusia dapat dilakukan dengan baik, pertumbuhan flora dan fauna semakin meningkat dan tidak terganggu. Biopori juga mencegah terjadinya erosi tanah dan bencana tanah longsor serta mengurangi pencemaran terhadap air. Biopori yang ada di lahan penanaman dekat posyandu sedapurklagen benjeng gresik sangat membantu dalam proses menghindari genangan air (run off water).

Berikut merupakan foto-foto kegiatan saat pelaksanaan dalam mmbuat tong sampah komposter dan pipa biopori.

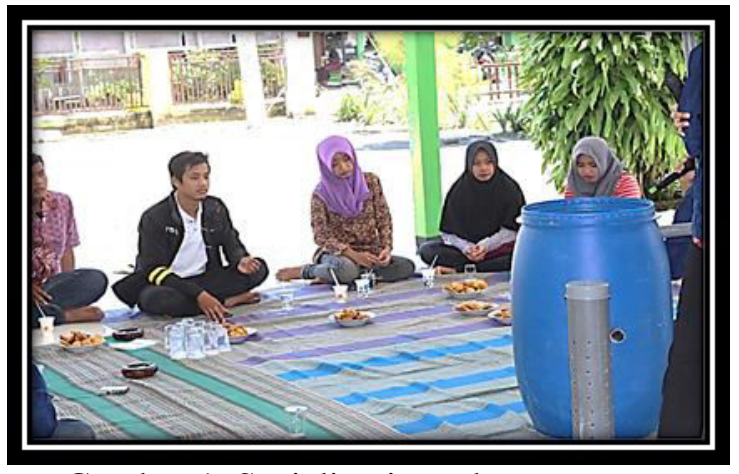

Gambar 1. Sosialisasi pembuatan tong sampah komposter dan pipa biopori

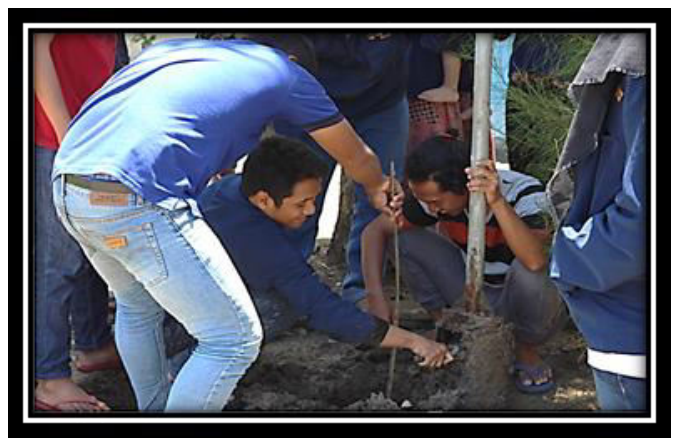


Gambar 2. Pengerukan tanah untuk penanaman pipa biopori dan tong sampah komposter

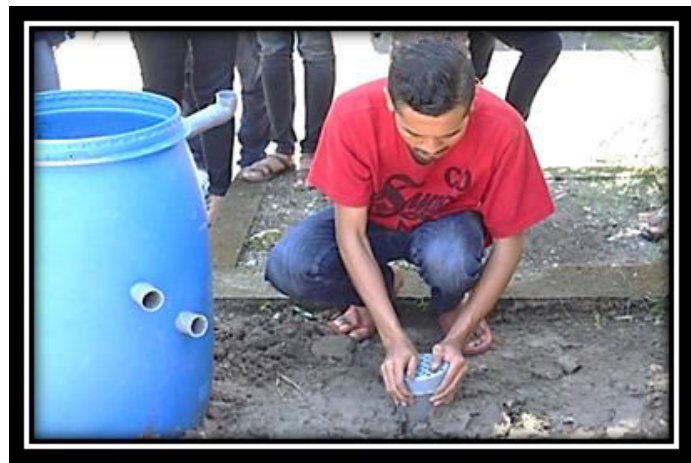

Gambar 3. Penanaman pipa biopori dan tong sampah komposter di lahan penanaman dekat posyandu sedapurklagen

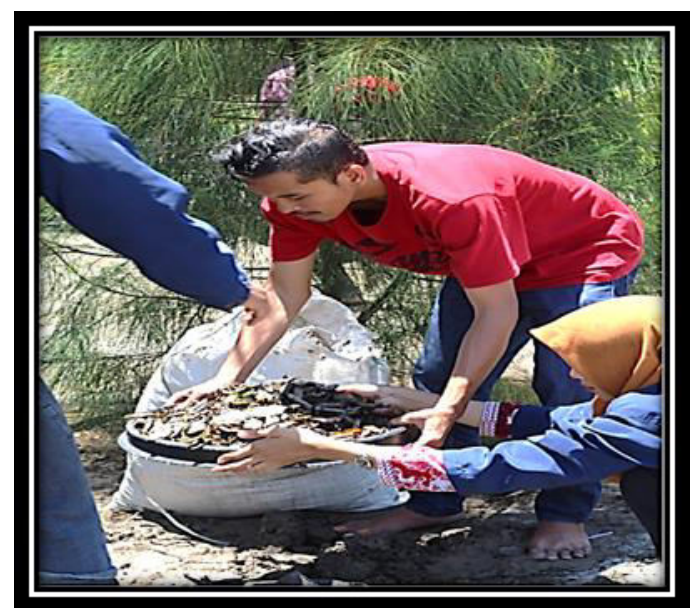

Gambar 4. Pengisian tong sampah komposter

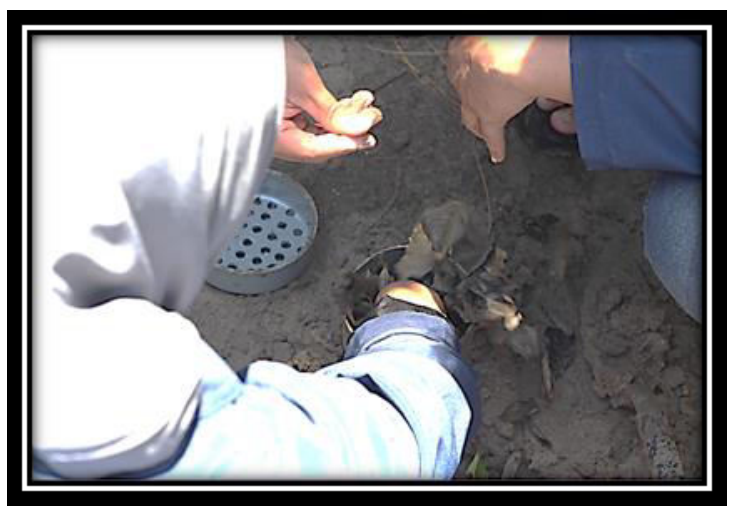

Gambar 5. Pengisian sampah organik ke dalam pipa biopori

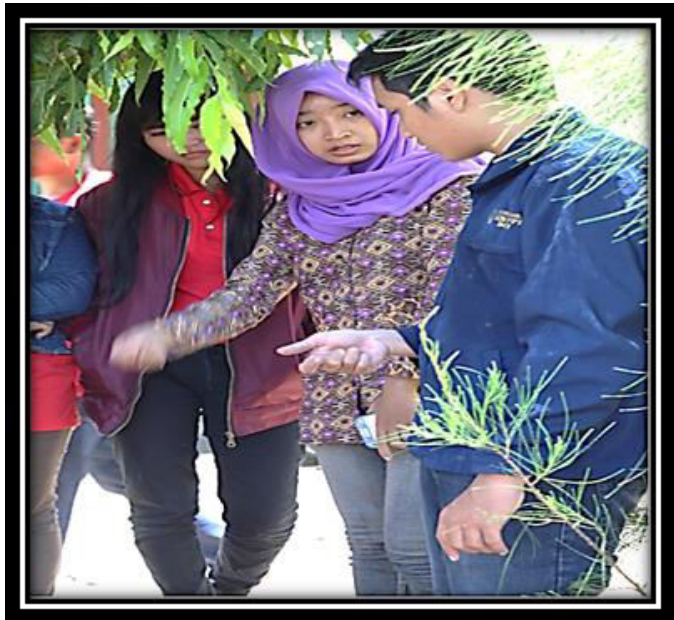

Gambar 6. Tanya jawab tentang pembuatan, dan penggunaan tong sampah komposter dan pipa biopori

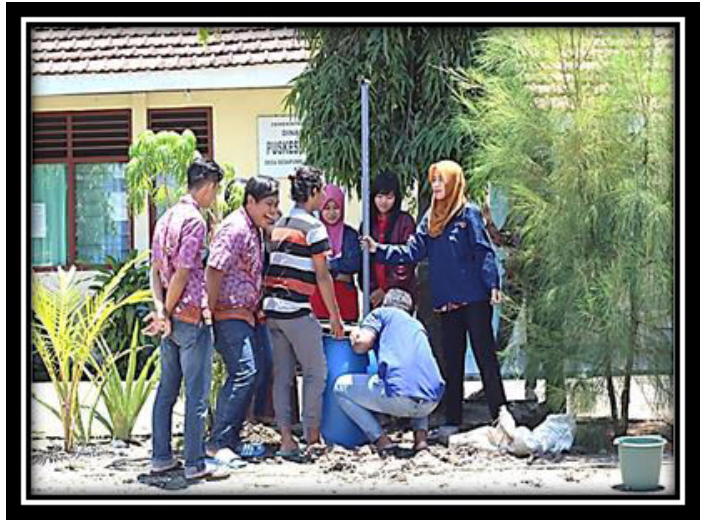

Gambar 7. Tong sampah komposter dan pipa biopori siap digunakan

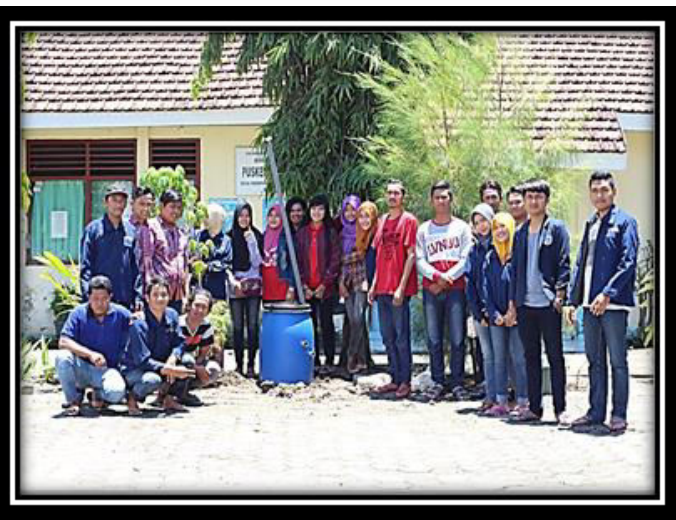

Gambar 8. Foto bersama dengan karang taruna setelah pembuatan tong sampah komposter dan pipa biopori. 


\section{KESIMPULAN}

\section{Kesimpulan}

Berdasarkan tujuan di atas dapat ditarik kesimpulan bahwa proses pembuatan tong sampah komposter dan biopori di lahan penanaman dekat posyandu sedapurklagen benjeng gresik warga di sekitar dapat mengetahui bagaimana cara mengolah sampah organik yang biasanya dibuang dan tidak dimanfaatkan menjadi bahan untuk pembuat kompos dan juga meminimalisir terjadinya banjir di lingkungan sekitar.

Tong sampah komposter dan pipa biopori yang ada di lahan penanaman dekat posyandu sedapurklagen benjeng gresik sangat membantu dalam proses pembuatan komposter rumahan dan menghindari genangan air (run off water) sehingga di lahan penanaman dekat posyandu sedapurklagen benjeng gresik dapat mengolah sampah dengan benar.

\section{Saran}

Kesadaran masyarakat sekitar akan masalah sampah perlu diperhatikan ketika sampah itu dikelola dengan baik, diolah sebagai pembuatan kompos melalui tong komposter dan dalam pembuatan biopori sebagai resapan air. Kesadaran sosial juga harus ditumbuhkan dalam kelestarian lingkungan agar pemanfaatan sampah organik dan permasalahan banjir dapat teratasi. Peran pemerintah dalam mengatasi permasalahan lingkungan sangat dibutuhkan untuk memberikan sosialisasi atau membuat kebijakan pemanfaatan sampah organik dengan melalui pengolahan sampah menjadi kompos dan pembebasan lahan untuk pembuatan resapan air.

\section{UCAPAN TERIMA KASIH}

Penulis mengucapkan terimakasih kepada Lembaga Penelitian dan Pengabdian Masyarakat Universitas PGRI Adi Buana Surabaya atas dukungan dana yang diberikan untuk keberhasilan dalam pelaksanaan pembuatan tong sampah komposter dan pipa biopori di desa Sedapurklagen Kecamatan Benjeng Kabupaten Gresik.

\section{REFERENSI}

Anonymous. (2002). Tata cara teknik operasional pengelolaan sampah perkotaan SNI 19 - 2454 - 2002. Jakarta, Indonesia.

Asdak, C. (2014). Hidrologi dan Pengelolaan Daerah Aliran Sungai (edisi enam). Yogyakarta: Gadjiah Mada University Press.

Bahar. (2008). Efektifitas Manajemen Penanganan Sampah Pada Wilayah Perkotaan dengan Konsep Sistem Informasi Manajemen Berbasis Database. Progresif, 4(1), 365-430. Retrieved from http://ojs.stmikbanjarbaru.ac.id/index.php/progresif/ar ticle/view/67

BPS. (2017). Statistik Lingkungan Hidup Indonesia Environment Statistic of Indonesia 2017. Jakarta. Retrieved from

https://unstats.un.org/unsd/environmen t/Compendia/Statistik Lingkungan Hidup Indonesia 2017.pdf

Brata, K. R., \& Nelistya, A. (2008). Lubang Resapan Biopori (Edisi 1). Jakarta: Jakarta Penebar Swadaya.

Dikominfo. (2017). Profil Kabupaten Gresik Tahun 2017. Retrieved from http://gresikkab.go.id/media/Statistik Kabupaten/profil statistik gresik 2017.pdf

Hariyono, P., Suciarto, S., Kusdiartini, V., \& Listiati, E. E. (2013). Kesadaran Pemilahan Sampah Rumah Tangga Pada Masyarakat Kota Semarang dan Yogyakarta. Sari Kajian Jurnal, 15(1), 59-66. Retrieved from https://www.neliti.com/publications/22 1466/kesadaran-pemilahan-sampahrumah-tangga-pada-masyarakat-kotasemarang-dan-yogyak

Hartini, E., Mubarokah, K., \& Mahawati, E. (2018). IBM Pemberdayaan Kader Dalam Mengelola Taman Obat Keluarga Melalui Komposting. ABDIMASKU, 1(1), 10-17. Retrieved from

http://abdimasku.lppm.dinus.ac.id/inde x.php/jurnalabdimasku/article/view/2/1 
Juliandari, M., Nirmala, A., \& Yuniarti, E. (2013). Efektivitas Lubang Resapan Biopori Terhadap Laju Resapan ( Infiltrasi ). Jurnal Teknologi Lingkungan Lahan Basah, 1(1), 1-10. Retrieved from jurnal.untan.ac.id/index.php/jmtluntan/ article/view/3441

Lindarto, D., Harisdani, D. D., \& Abdillah, W. (2018). Partisipasi Masyarakat Dalam Penggunaan Teknik Biopori Untuk Mengendalikan Banjir Kota (Studi Kasus : Kelurahan Tanjung Rejo - Medan). NALARs Jurnal Arsitektur, 17(2), 97-104. http://doi.org/10.24853/nalars.17.2.\%p

Mulyaningsih, T., Purwanto, P., \& Sasongko, D. P. (2014). Status Keberlanjutan Ekologi pada Pengelolaan Lubang Resapan Biopori di Kelurahan Langkapura Kecamatan Langkapura Kota Bandar Lampung. Sains Tanah, 11(2), 85-94. Retrieved from jurnal.fp.uns.ac.id/index.php/tanah/arti cle/view/224

Rangkuti, F. A. (2014). Dampak Keberadaan Tempat Pembuangan Akhir Sampah ( TPAS ) " Namo Bintang " Terhadap Masyarakat (Studi Kasus: Desa Namo Bintang, Kecamatan Pancur Batu, Kabupaten Deli Serdang). Institut Pertanian Bogor. Retrieved from https://repository.ipb.ac.id/handle/1234 56789/68817

Rauf, A. (n.d.). Optimalisasi Pengelolaan Lahan Pertanian Hubungannya dengan Upaya Memitigasi banjir. Medan. Retrieved from http://repository.usu.ac.id/bitstream/ha ndle/123456789/20602/ppgb_2009_Ab dul

Rauf.pdf?sequence $=1 \&$ isAllowed $=\mathrm{y}$

Sahwan, F. L. (2012). Analisis Proses Komposting Pada Pengelolaan Sampah Berbasis Masyarakat Skala Kawasan (Studi Kasus di Kota Depok). Jurnal Teknologi Lingkungan, 13(3), 253260. Retrieved from http://ejurnal.bppt.go.id/index.php/JTL /article/view/1394
Setiono, D. A. (2017). 9 Desa di Benjeng Masih Terendam Banjir. Retrieved August 15, 2018, from http://www.beritajatim.com/peristiwa/ 289100/9_desa_di_benjeng_masih_ter endam_banjir.html

Suartami, N. W. E. (2016). Analisis Harga Pokok Produksi Pengolahan Sampah Pada Program 3R RKM Dalam Mewujudkan Culik Bersin. Pendidikan Ekonomi Undhiksa, 8(3), 1-11. Retrieved from https://ejournal.undiksha.ac.id/index.p $\mathrm{hp} / J J P E /$ article/view/8718

Wahyono, S. (2016). Analisis Efektivitas Konsep Pengelolaan Sampah Organik Melalui Teknologi Komposting (Studi Kasus di Kota Probolinggo, Jawa Timur). Teknologi Lingkungan, 17(1), 37-44. Retrieved from http://ejurnal.bppt.go.id/index.php/JTL /article/viewFile/1463/1255

Widyastuti, S. (2013). Perbandingan Jenis Sampah Terhadap Lama Waktu Pengomposan Dalam Lubang Resapan Biopori. Jurnal Teknik WAKTU, 11(01), 5-14. Retrieved from jurnal.unipasby.ac.id/index.php/waktu/ article/download/894/736 
VOL. 03. NO. 1, JANUARI 2019 